has also been described in a child who had been vaccinated three weeks previously with live measles virus vaccine accompanied by gammaglobulin. ${ }^{15}$

Many viruses are now known to remain latent within the tissues for long periods of time, including cytomegaloviruses and adenoviruses as well as those of herpes simplex, herpes zoster, and measles. The possibility discussed by Dr. Webb that the immune response to a different virus might disturb the relationship between the host and a virus latent in his tissues is one which requires careful thought and further study.

\section{Medical Assistants}

Many doctors are uneasy about the medical assistant grade. They fear that assistants are being used to do consultant work for less pay, and that doctors who fall behind in the competition for consultant posts will be shunted into the grade and forgotten. After a long debate at the Annual Representative Meeting at Eastbourne ${ }^{1}$ the B.M.A. asked the Ministry of Health to create no further new full-time medical assistant posts for the time being, and the Ministry agreed. ${ }^{2}$

Tables published in the Supplement this week (p. 57) answer many of the questions asked about the medical assistant grade. There are about 2,000 full-time assistants in Britain. Most of them are former S.H.M.O.s and J.H.M.O.s, and as these doctors retire or die their appointments are often regraded or abolished. Hence the total number of "nonconsultant career grade " posts is falling. On the other hand, the number of medical assistant posts that were not formerly S.H.M.O. or J.H.M.O. appointments is rising: about 140 new posts are created each year.

What sort of doctors fill these new posts? The tables show that most new medical assistants are registrars or senior registrars who have spent over four years in those grades-at least 29 had been in post 9 years or more ; and that a third of them are foreign graduates. So the suspicion is confirmed that the medical assistant grade is often being used to mop up the surplus of doctors from so-called training grades who fail to secure consultant appointments.

Under the present system any doctor who wants to do so can get a foot on the ladder leading to consultant status, and while the number of training posts remains disproportionately high most of the hospital junior staff cannot reach the top. Reform of the career structure seems likely in the near future, and many think that only the abolition of non-consultant career appointments can lead to a fair system. Abolition of the medical assistant grade would have two effects. Firstly, in specialties such as ophthalmology and psychiatry particularly, much more routine work would have to be done either by consultants or by general practitioners with part-time appointments ; and, secondly, selection for training posts would have to be much more strict.

Not every doctor selected for training can be expected to fulfil his promise of achieving consultant ability. Some sort of career must be open to those doctors who fail to make the grade, and there is work in the hospital service for such doctors. But the number of these posts and the acceptable failure rate in the training system should be decided on objec-

1 Brit. med. F. Suppl., 1968, 3, 8.

Brit. med. F. Suppl., 1968, 3, 98.

- Report of the Royal Commission on Medical Education, 1968 H.M.S.O. tive grounds, and not be determined by a process of laisser faire. Full-time medical assistant posts are one solution, but it is by no means clear that they are the best or the only answer to the problem.

The Department of Health and Social Security is understood to be anxious for some relaxation of the moratorium on new medical assistant posts so that service needs can be met. Though the request for the moratorium came from the B.M.A., the Ministry is in consultation with the Joint Consultants Committee on this matter, as the J.C.C. is the official negotiating body for staffing problems in the hospital service. Last week the Conference of Hospital Medical Staffs asked that the moratorium should remain in force until the B.M.A. and the Royal Colleges have put forward their views on the proposals made in the Todd Report ${ }^{3}$ that the medical assistant grade should be replaced by one of fully trained hospital specialist. A Todd specialist would differ from today's medical assistant in having received a three-year period of general professional training, followed by a further period of specialist training leading to vocational registration.

Until uncertainty about the future of the medical assistant grade is resolved new appointments should not be made except in cases where the service need is unarguable and urgent, and these will be very few.

\section{Prostaglandins}

"Prostaglandin" was the name given by U. S. von Euler in 1935 to a substance found in human seminal fluid. ${ }^{1}$ Von Euler showed that this lipid-soluble, acidic compound stimulated smooth muscle and lowered blood pressure. The biological activity of "prostaglandin" is now known to be due to several closely related compounds, the prostaglandin $\mathrm{E}$ and $\mathrm{F}$ series, which are formed from essential fatty acids. To date, prostaglandins have been identified in a variety of tissues including brain, iris, thymus, heart, lungs, liver, pancreas, kidney, menstrual fluid, umbilical cord, decidua, and amniotic fluid.

Though their physiological function in the body remains unknown, the work of S. M. M. Karim and his colleaguesfirst at Queen Charlotte's Hospital in London, and now at Makerere University College in Uganda-has focused attention on the possible role of prostaglandins in initiating labour in human pregnancy. In 1966 Karim identified four prostaglandins- $\mathrm{E}_{1}, \mathrm{E}_{2}, \mathrm{~F}_{1 a}$ and $\mathrm{F}_{2 a}$-in human amniotic fluid. ${ }^{2}$ Subsequently he showed that the last two were found in the amniotic fluid of patients only during labour. ${ }^{3}$ He suggested that these amniotic-fluid prostaglandins might be derived from the decidua.

Two further articles by Karim and his colleagues were published in last week's B.M.F. The first paper described the identification of prostaglandin $F_{2 a}$ in the peripheral blood of pregnant women in labour. ${ }^{4}$ During labour the blood concentration of prostaglandin $F_{2 a}$ was related to uterine

\footnotetext{
1 Euler, U. S. von, Klin. Wschr., 1935, 14, 1182.

2 Karim, S. Von, Obstet. Gynaec. Brit. Cwlth, 1966, 73, 903.

3 Karim, S. M. M., and Devlin, Jean, f. Obstet. Gynaec. Brit. Cwlth, $1967,74,230$.

Karim, S. M. M., Brit. med. F., 1961, 4, 618.

- Karim, S. M. M., Trussell, R. R., Patel, R. C., and Hillier, K., Brit. med. F. 1968, 4, 621.

Bygdeman, M., Kwon, S. U., Mukherjee, T., and Wiqvist, N., Amer. f. Obstet. Gynec., 1968, 102, 317.

' Bergström, S., and Samuelsson, B., Endeavour, 1968, 27, 109.
} 
activity, reaching a peak just before and during a contraction, and falling rapidly after the uterus relaxed between contractions. The second paper described the successful induction of labour by the intravenous infusion of prostaglandin $\mathrm{F}_{2 a}{ }^{5}$ The time interval from the start of the infusion to delivery of the baby varied from two to twelve hours in 10 patients of differing age and parity, all at or near term. No untoward effects on mother or baby were apparent.

These findings for prostaglandin $F_{2 a}$ are in contrast to a recent report about prostaglandins of the $\mathrm{E}$ series by $M$. Bygdeman and his colleagues in Stockholm. They gave prostaglandins $E_{1}$ and $E_{2}$ by intravenous infusion to pregnant women at term, but found that the substances caused an " unphysiologic elevation of tonus," and so were unsuitable for inducing labour. Nevertheless, the findings by Karim and his colleagues will doubtless stimulate further work on the physiological importance of prostaglandins in human pregnancy, particularly in relation to the onset of labour, the cause of which is still unknown. Certainly the prostaglandins have potent biological effects, and are said to modulate intracellular metabolism, ${ }^{7}$ but if they are to be implicated as a regulating factor in the initiation of labour several questions will have to be answered. What is the source of these prostaglandins ? How are they released in late pregnancy ? What is their action on the pregnant myometrium at a cellular level?

It would be difficult for any drug to supersede intravenously administered oxytocin for the induction of labour unless it caused neither uterine hypertonus when infused in excessive amounts nor an antidiuresis. But if it is found to be free from these side-effects (which limit the usefulness of oxytocin) intravenous infusion of prostaglandin $F_{2 a}$ could eventually become the method of choice for inducing labour in human pregnancy.

\section{Rhodesia's First Medical Graduates}

The final examination at the medical school of the University College of Rhodesia last month was the first to be held there. It is gratifying to note that out of 17 candidates 16 passed and the 17 th failed in one part only. Three candidates gained honours. The qualification these students achieved is the M.B., Ch.B. of the University of Birmingham, and they are therefore eligible for registration not only in Rhodesia but with the General Medical Council of the United Kingdom and Ireland. The association between Birmingham and Salisbury requires some explanation.

In 1955 the University College of Rhodesia and Nyasaland, which had opened its doors that year, asked the Nuffield Foundation if it would arrange an inquiry into the possibility of adding a medical school to the college. The Nuffield Foundation therefore set up a committee, ${ }^{1}$ which over the ensuing few years met frequently in London and visited the Rhodesias and Nyasaland (as they were then called). In two reports it supported the foundation of a medical school and outlined the basis on which it thought the school should develop. The University College at Salisbury accepted the reports, and financial support from various sources was secured, including $£ 250,000$ from the Nuffield Foundation.

As all concerned in Salisbury were anxious that the qualifications gained in the school should have recognition by the General Medical Council it was necessary to consider some system of sponsorship. The college itself is sponsored by the University of London, but it was felt that an association of the medical school with some other university might be appropriate, a view with which the University of London concurred. There was naturally in the foundation committee a certain amount of rivalry about which school in the United Kingdom could secure this attractive educational opportunity. The choice of Birmingham depended largely on the discovery that its charter, granted in 1900, empowered the university to affiliate and recognize for purposes of instruction and examination colleges outside Birmingham. Legal opinion confirmed that there was no impediment to the University of Birmingham proceeding without further ado to the sponsorship of the new medical school in Rhodesia.

At this point it is important to emphasize that the Royal Charter of the University College is explicit that it is open to students irrespective of race, creed, or colour. In fact it has been from its foundation and is now an absolutely multiracial college in which the three racial groups of European, African, and Asian have complete equality in both their residential and their academic life.

Staff were recruited, and the medical school opened its doors in 1962 to the first intake of about 25 students, mainly of European stock but with several Africans and Asians. Until now the course has covered a full six years, entrance to which is on the basis of two " $A$ " levels in the G.C.E. It is proposed in the near future to amend it to a five-year course with direct entry into the first preclinical year, as there are now enough applicants with adequate "A" levels in physics, chemistry, and biology. The proportion of Africans has risen steadily in each annual intake as the result of the increasing output of the sixth forms of African schools.

The preclinical school is well housed in fine buildings on the college campus. The erection of the multiracial teaching hospital on the campus has been delayed in the present troubles, but there is a determination to proceed with this building as soon as posible, and an early announcement of intent by the Rhodesian Government is eagerly awaited. Meanwhile the clinical school is in the Harari African Hospital. Though in many respects an excellent hospital, it is unfortunately some seven miles from the main campus and its patients are exclusively African. This has meant that the European students lack clinical clerking on patients who speak their mother tongue.

Thirteen years can be regarded as a comparatively short period to elapse between the first step to a medical school's foundation and the emergence of its first graduates. Much of that period has been clouded by political unrest, but fortunately this has not seriously impaired the development of the school. Matters of education and health have been specifically excluded from sanctions, and the British Government and the Government in Rhodesia, despite many problems, have continued to support the college and the medical school.

The progress of the school reflects credit on many people. Among them may be specially noted Dr. Richard Morris, who was Secretary of Health of the Federation during the early 1950s and one of the chief sponsors of the school. He was followed as Secretary of Health by Dr. Dyson Blair and then by Dr. Mark Webster, who have done everything in their power to nurture the growing school. A renowned member of its staff is Professor Michael Gelfand, who occupies the

\footnotetext{
Members:Mr. L. Farrer-Brown (chairman), Professor Melville Arnott, Professor T. H. Davey, Professor David Greenfield, Sir Peter Medawar, F.R.S., the Hon. Honor B. Smith, and Professor R. Milnes Walker.
} 